Article

\title{
The Impact of a Summer Sports Camp for Children with Visual Impairments on the Self-Efficacy of Physical Education Pre-Service Teachers: A Pilot Study
}

\author{
John T. Foley ${ }^{1 *}$, Sara Santarossa ${ }^{2}$, Dan W. Tindall ${ }^{3}$ and Lauren J. Lieberman ${ }^{4}$ \\ Received: $8^{\text {th }}$ February 2019; A ccepted: $3^{\text {rd }}$ September 2019; Published: 27 $7^{\text {th }}$ A pril 2020
}

\begin{abstract}
Training and self-confidence of the instructor are important components in the success of any inclusive physical education (PE) or recreation program. The purpose of this study was to determine if the self-efficacy toward teaching students with intellectual disabilities, physical disabilities or visual impairment in PE would increase in PE pre-service teachers working at a one-week intensive sports camp for youth with visual impairments. PE pre-service teachers $(n=18)$ filled out the Self-Efficacy Scale for Physical Education Teacher Education $M$ ajors towards Children with Disabilities (SE-PETE-D) pre- and post-camp. SE-PETE-D measured participants' self-efficacy toward including students with disabilities. Participant's selfefficacy for teaching youth with a visual impairment scores significantly increased during camp, $t(17)=3.75, p=.002, d=0.88$. A similar pattern was observed in self-efficacy for teaching youth with an intellectual disability and physical disability, with scores also significantly increasing, $t(17)=5.32, p<.001, d=1.25$ and $t(17)=3.83, p=.001, d=.90$, respectively. Results from this study suggest teaching and learning experiences that are both practical and disability-orientated can be quite effective in increasing PE pre-service teacher's confidence working with youth with disabilities.
\end{abstract}

Keywords: Disability A wareness; Teacher Preparation; Camp A bilities

\section{Introduction}

Including students with disabilities into general education has become a common practice in the U nited States (U.S. D epartment of Education, 2008), and it is progressively becoming an educational model in other countries around the world (Camerini, 2011; M inistry of Education and H uman Resources, 2007). According to a resolution put forth by the U nited $\mathrm{N}$ ations (U nited N ations General Assembly Resolution $61 / 146,2006)$, all members of the UN must warrant equal education for all children. However, teachers have expressed various barriers when having to teach students with disabilities, including inadequate training (K won, 2018; Piletic \& Davis, 2010) and professional development, a feeling of limited support (Kodish, Kulinna, Martin, Pangrazi \& Darst, 2006), lack of competence, large class sizes, time, and administrative demands (Konza, 2008; Rust \& Sinelnikov, 2010). Teachers also worry about the lack of support, their competencies as well as the safety and participation of students (Rybová \& Kudláček, 2013). In addition, an important determinant of implementing successful inclusion of students with disabilities is a teacher's belief related to his/her abilities to affect the learning outcomes of students, referred to as teacher self-efficacy (Kodish et al., 2006; Tschannen-M oran \& Hoy, 2001).

"Self-efficacy" is defined by Bandura (1997) as one's "beliefs in one's capabilities to organize and execute the courses of action required to produce given attainments" (p.3). Self-efficacy beliefs mirror one's capabilities to implement control over events and estimations of capability to perform given tasks (Baloun, Kudláček, Sklenaříková, Ješina, \& Migdauová, 2016). It is theorized that self-efficacy information is 
acquired from physiological and emotional states such as anxiety and stress (Bandura, 1997) and in turn provide people with cues about an anticipated success or failure. A teacher's self-efficacy may be lowered when they experience negative thoughts and fears about their capabilities (e.g., negative outcomes, failure to improve performance, or complaints from administration). Conversely, teachers with a higher selfefficacy approach difficult tasks as challenges to be mastered, persevere in the face of failure, and recover quicker after setbacks (Schunk, 2012). M oreover, the teachers set higher goals for themselves, establish strategies to accomplish their goals, believe their attainment of the goals is valuable, and maintain their motivation over time (Schunk \& Pajares, 2009). Therefore, unless teachers believe they can produce a desired effect by their action, they have little incentive to act (Baloun et al., 2016). Thus, it is imperative that teachers have high level of self-efficacy when teaching to all children, because if they do not they may come to believe that inclusion could be unsuccessful. Specifically, a link between teacher self-efficacy and professional development, (M artin, McCaughtry, Hodges-Kulinna, \& Cothran, 2008; Martin, M CCaughtry, Kulinna, Cothran, \& Faust, 2008), and teachers' and students' behavior (Martin \& Kulinna, 2004 ; 2005) has been found in physical education (PE) research.

Block and Obrusnikova (2007) have suggested that it can be a challenge for physical educators to accommodate students with disabilities in the PE setting, this is particularly the casefor children with visual impairments (Lirgg, Gorman, M errie, \& Shoemake, 2017). Lieberman and colleagues (2002) found that PE teachers view the lack of professional preparation as a leading barrier to including students with visual impairments in their classes. Physical activity and PE programs for students with disabilities have the potential to developed self-esteem and create problem solving opportunities (Kress \& Lavay, 2006), thereby enabling transformational experiences wherein individual physical limits can be tested and new selfdefined standards and capabilities determined. Therefore, an important element in the attainment of any inclusivity, and ensuring persons with disability are able to fully experience the benefits of PE and physical activity, is training and self-confidence of the instructor (Block \& Rizzo, 1995; Lepore, Gayle, \& Stevens, 1998).

It has been noted in the literature that opportunities exist in disability-only or segregated summer programs that give PE pre-service teachers opportunities to support a student with a disability (Goodwin, Li eberman, Johnston, \& Leo, 2011; Goodwin \& Staples, 2005); developing skills and abilities that can lead toward inclusivity. Researchers have also revealed a positive impact on the self-efficacy of participants in these disability-only summer programs (Shapiro, M offett, Lieberman, \& D ummer, 2005; Tindall, Foley, \& Lieberman, 2016). H owever, there is a paucity of research referring to the impact on the self-efficacy of PE pre-service teachers in this setting (Tindall, Culhane, \& Foley, 2016). Therefore, the purpose of this study was to determine if the self-efficacy of PE pre-service teachers (working at a one-week intensive sports camp for youth with a visual impairment, for the first time) would increasetowards teaching students with intellectual disabilities, physical disabilities, or visual impairment in PE.

\section{Materials and Methods}

\section{Participants}

"Coaches" at this overnight sports camp for children and youth with visual impairments, blindness, or deaf blindness provide one-on-one support for an "athlete" (i.e. camper). These volunteer "coaches" were undergraduate students from various university programs (e.g., special education, PE, adapted PE) who were receiving adapted physical activity practicum course credit (Lieberman, Lepore, \& Haegele, 2014). This course content included a day and a half orientation and the 90 hours of practicum teaching a child with a visual impairment one on one. The pre-service teachers submitted a portfolio with required journal reflections, sample assessments used, specific descriptions of modifications and instructional strategies. Participants in the current study included "coaches" that were PE pre-service teachers present during the entire week at a summer camp for children with a visual impairment. All participants were experiencing working at this particular summer camp, for children with a visual impairment, for the first time. The children at this camp were between 9-19 years old, came from varying race or ethnic backgrounds, and had a visual impairment (i.e., have a vision teacher) with varying levels of visual acuity. 
The coaches' duties included overall camp supervision, instructional support, social support, and guiding assistance promoting mobility and independence (Goodwin et al., 2011).

\section{Measures}

\section{Self-Efficacy Scale for Physical Education Teacher Education Majors towards Children with Disabilities (SE-PETE-D)}

TheSE-PETE-D is a measure designed to assess PE pre-service teachers' self-efficacy toward including students with intellectual disabilities (11-items), physical disabilities (12-items), and visual impairment (10-items) in PE frameworks; including teaching skills, playing sport games and performing fitness activities (Block, H utzler, Barak \& Klavina, 2013). A vignette demonstrating a student with an intellectual disability, a physical disability, or a visual impairment who would be attending a PE class is presented to the participants. Participants are asked to rate their degree of confidence to complete situational-specific PE activities for each of the targeted disabilities. Items were scored on a 5-point Likert scale ranging from 1 (no confidence) to 5 (complete confidence). Within each disability, subscale item scores were averaged, with higher scores indicating greater confidence. A sample statement, proceeding a vignette, is "How confident are you in your ability to keep Noah on task during fitness testing?". Versions of the scale have been translated into Spanish (Reina, H emmelmayr, \& Sierra-M arroquín, 2016), Czech (Baloun et al, 2016; Kudláček, Baloun, \& Ješina, 2018), and Lithuanian (Selickaitè, Hutzler, Pukènas, Block, \& Rèklaitienė, 2019). Consistent with the English version, all translated versions have reported acceptable reliability and validity.

\section{Procedures}

As part of the pre-camp in-service preparation, PE pre-service teachers went through an eight and a half hour training program (Lieberman et al., 2014) provided by sport specialist (i.e., a gymnastics instructor who also specializes in visual impairments) within each individual sport offered at the camp. Training consisted of an overview of visual impairments, instruction techniques, feedback techniques, modification strategies, and the rules and instructional strategies for each sport. There were experienced sport specialists at each sport to help guide the instruction, modifications, assessment, and feedback of the lessons. In addition, to build empathy and understanding, participants had the opportunity to experience each sport with occluded vision, simulating what the athlete would experience during the various activities.

The following was the camp orientation schedule: 1) Introductions \& ice breakers (30 minutes), 2) Overview of eye conditions (30 minutes), 3) H ow to treat a person who is blind (30 minutes), 4) H uman guide techniques (30 minutes), 5) Tactile instruction/Physical guidance/Tactile modeling (60 minutes) 6) Emotionally and physically safe environment (30 minutes), 7) A ssessment \& motivational techniques (30 minutes), 8) M eet with each group and review athlete profile (30 minutes), 9) Goalball (30 minutes), 10) Beep Baseball (30 minutes), 11) Tandem Biking (30 minutes), 12) Track \& Field (30 minutes), 13) Standup Paddle Board (30 minutes), 14) Gymnastics (30 minutes), 15) Aquatics (30 minutes), \& 16) Judo (30 minutes). The sport specialists offered guidance and support, as well as feedback when needed. Throughout the week the sport specialists would provide the framework for the lessons to be used by the PE pre-service teachers when working with the campers.

Prior to the start of training and to athletes arriving at camp, participants signed consent forms, and completed a paper version of the SE-PETE-D. A week later (i.e., 7 days), after campers left the camp, participants again completed the SE-PETE-D. The Institutional Review Board at State U niversity of N ew York (application \#151655) approved all procedures.

\section{Data analysis}

While there is debate within many fields on the best approach to analyze Likert type scales; if they are normally distributed and a wide range in the data, parametric statistics may be used (Kaptein, Nass, \& M arkopoulos, 2010; N orman, 2010). After checking the distribution of the data, paired t-tests were used to determine if significant differences existed in the individual subscale scores between first day and last day 
at camp. Effect sizes were calculated and interpretation was based on Cohen's (1992) recommendation of $d=.2$ a small effect, $d=.5$ a medium effect and $d=.8$ a large effect. Data were analyzed in Stata 13 for Windows. Alpha was set at .05.

\section{Results}

The 18 participants ( females $=13$; males $=5$ ) in the study ranged in age from $19-33$ years old $(M=23$ years old, $S D=3$ years). When asked "What are your experiences with the following students with physical, intellectual, or visual disabilities in physical education or community sports?" most of the participants indicated that they had three or more experiences with students with disabilities, however that interaction largely varied across the three disability categories VI $=27.8 \%, P D=66.7 \%, \&$ ID $=72.2 \%$. When asked "What are your personal experiences with people with intellectual, physical, or visual disabilities?" participants had little personal experience with disability from family exposure with only 1-2 people indicating that they had a family member with a VI, PD, or ID. Conversely, most participants reported having personal experiences with persons with disabilities at school across the three disability categories $\mathrm{VI}=72.2 \%, \mathrm{PD}=83.3 \%, \& I D=88.9 \%$. This previous exposure may explain the high starting (Pre) selfefficacy scores at the beginning of camp as seen in Table 1.

There was a significant difference in the PE pre-service teacher's self-efficacy scores for teaching a student with an intellectual disability $t(17)=5.32, p<.001, d=1.25$, for teaching a student with a visual impairment $\mathrm{t}(17)=3.75, \mathrm{p}=.002, \mathrm{~d}=0.88$, and a student with a physical disability $\mathrm{t}(17)=3.83, \mathrm{p}=.001, \mathrm{~d}$ $=.90$ (Table 1). The effect size for the change in all three sub-scores were high, suggesting that physical education pre-service teachers can significantly improve their self-efficacy when working with kids with different disabilities during an intensive one-week sports camp.

Table 1: M ean, standard deviation and 95\% confidence intervals of self-efficacy subscale scores.

\begin{tabular}{lllllll}
\hline & \multicolumn{2}{c}{ Intellectual Disability } & \multicolumn{2}{l}{ Visual Impairment } & \multicolumn{2}{l}{ Physical Disability } \\
& $\mathrm{M}(\mathrm{SD})$ & $(95 \% \mathrm{Cl})$ & $\mathrm{M}(\mathrm{SD})$ & $95 \% \mathrm{Cl}$ & $\mathrm{M}(\mathrm{SD})$ & $95 \% \mathrm{Cl}$ \\
\hline Pre & $3.91(.66)$ & $(3.54-4.18)$ & $4.19(.70)$ & $(3.74-4.47)$ & $4.19(.71)$ & $(3.77-4.48)$ \\
Post & $4.67(.43)$ & $(4.33-4.85)$ & $4.76(.36)$ & $(4.50-4.90)$ & $4.71(.41)$ & $(4.42-4.88)$ \\
Cohen's d & 1.25 & & 0.88 & & 0.90 & \\
\hline
\end{tabular}

\section{Discussion}

The purpose of this study was to determine if the level of self-efficacy among pre-service teachers at a specifically designed sports camp for youth with visual impairments would increase towards teaching students with intellectual disabilities, physical disabilities, or visual impairment in PE. Results from this study suggest increases to the PE pre-service teacher's level of self-efficacy in teaching to students with disabilities, teaching and learning experiences that are both practical and disability-orientated can be quite effective. Additionally in these findings are the noticeable increases across all three subscale areas in the self-efficacy levels of the "coaches" working with children and young people with a visual impairment as part of this one-week intensive sport camp experience. These outcomes are similar but unique to those found in previous research that focused on PE pre-service teachers who participated in a more prolonged (once a week across 8-9 weeks) disability practicum experience (T aliaferro, $\mathrm{H}$ ammond, \& W yant, 2015) or adapted physical activity setting (Tindall et al, 2016).

It should be noted that the participants came in with a relatively high self-efficacy to begin with (most scored at or above 4 on a 5-point scale). On the one hand, this suggests the group probably already had a background in APE because they were also the ones that chose to volunteer for this one-week summer program as part of their continued professional development. On the other hand, this meant that to reach significant improvement a large change had to take place. This was a very important point to add since their scores were al ready relatively high to begin with. Causes of this largejump from an al ready good selfefficacy score may be due to the very focused nature of the program. The second mission of the Camp 
program was to train future teachers. This training consisted of the following; a one-and-a-half-day orientation, the purpose and use of expert sport specialists, the guided assessment strategies within each sport, feedback from the leaders of the camp, and the repetitive nature of the schedule (Lieberman et al, 2014; H aegele, Lieberman, Lepore, \& Lepore-Stevens, 2014).

According to Pendergast, Garvis, and Keogh (2011), the desire to become an effective educator is at the heart of a teacher's self-efficacy. It is this desire that ultimately influences theamount of time and effort the teachers spend in designing and implementing tasks used to help students meet their educational goals and objectives. H owever, when it comes to meeting the needs of students with disabilities, researchers have suggested that PE pre-service teachers do not feel truly prepared to do so in the current PE setting (Block, Taliaferro, H arris, \& Krause, 2010; Lirgg et al., 2017). Specifically, PE pre-service teachers have expressed a lack of both competence and confidence in providing effective learning experiences as well as adapting tasks for students with disabilities (A mmah \& Hodge, 2006; H ardin, 2005; Lienert, Sherrill, \& M yers, 2001) particularly children with visual impairments (Haegele, \& Zhu, 2017). This is in line with work of Kozub and Lienert (2003) who found that perceived competence is the variable most mentioned when examining the attitudes of PE teachers and their ability to work with students with disabilities. On its own, as stated by Casebolt and Hodge (2010), a teacher's level of self-efficacy in catering to students with disabilities can be directly linked to their capacity to effectively and realistically implement safe and appropriate activities for these individuals.

Perkins, Columna, Lieberman, and Bailey (2013), found that parents felt that the PE teachers of their children with visual impairments were not prepared to teach them. Gao and Mager (2011) were of the opinion that teachers' overall personal and general teaching self-efficacy and preparedness to enter the inclusive classroom would be enhanced if more time was spent during their initial training working in an inclusive or disability-orientated education setting, as opposed to training that was overly theoretical in nature and lacked any real life or relevant experiences. Earlier research by Clift and Brady (2005) and Morley, Bailey, Tan, and Cooke (2005) found similar results suggesting program design during initial teacher education should move towards more practice-based learning experiences and away from heavy traditional theory-based only courses. M ore recent studies continued to support this view recognizing that added practical content (balanced with theoretical content) should be provided to PE pre-service teachers as a means to further prepare them to work with children with disabilities in inclusive settings (D oulkeridou et al., 2011; Lancaster \& Bain, 2010). H owever, as alluded to earlier, it should be noted that these practical experiences should be realistic of what PE pre-service teachers will face in the PE setting.

\section{Strengths and limitations}

Although the sports camp used in this study may not truly reflect a realistic school-based setting, it did prove to be an effective background for participants to further develop both their self-efficacy and attitudes towards the inclusion of youth across disabilities in physical activity and sport. Given the extensive engagement of the PE pre-service teachers with campers on a daily basis, it was clear that many, if not all, had become confident in assisting their young athlete with visual impairment and as such increased their self-efficacy. While the change in scores could also be the result of familiarity with the test items, this does not appear to be the case. Future studies should seek to further understand the specific aspects of the program that had the greatest impact on self-efficacy of the PE pre-service teachers. Understanding these specific aspects influencing self-efficacy could be explored through qualitative exit interviews at the end of camp. In addition, a longer follow up (i.e., greater than 1 week) should be considered to determine if changes to self-efficacy is sustainable over time. Despite the strengths of the current study, which include contributing to the limited research on this topic, there are limitations that should be noted. Firstly, there were small number of participants who were a self-selected group of participants that chose to volunteer at the camp and thus may have already had a strong interest in PE for youth with visual impairments. Secondly, the high self-efficacy scores at the start of camp could be a product of preselection bias (volunteering to the camp), which may lead to limited generalization of the outcomes. While those pre-service teachers who have a preliminary high self-efficacy have presented a 
significant gain due to the experience, other pre-service teachers who have a low preliminary self-efficacy may feel threatened from a similar exposure. Ther efore, in order to generalize additional participants with low self-efficacy may have to be recruited in future studies. Finally, without a control group it is difficult to truly assess the impact of the program. Future research should explore if it is exposure to youth with visual impairments that changes self-efficacy in PE pre-service teachers, or if it is something unique about this sport-based camp, using a control group to increase scientific rigour.

\section{Perspectives}

In order to effectively develop self-efficacy in PE pre-service teachers, it is vital that these individuals are exposed to realistic and relevant practicum experiences when working with youth with disabilities. $\mathrm{H}$ aving future teachers participate in a sport camp like Camp A bilities can provide the realistic practicum experiences that would prepare them to handle the unique situations and environments that are part of working with students with disabilities.

\section{Author affiliations:}

1 State U niversity of N ew Y ork at Cortland, N ew York; john.foley@cortland.edu

2 University of W indsor, Ontario; santaros@uwindsor.ca

3 University of Limerick, Ireland; daniel.tindall@ul.ie

4 The College at Brockport, N ew York; llieberman@brockport.edu

* Correspondence: john.foley@cortland.edu; Tel.: +1-607-753-5531

Author Contributions: Conceptualization, JF, SS; M ethodology, JF, SS, DT, LL; Formal Analysis, JF, SS; W ritingOriginal Draft Preparation, SS, DT , LL; Writing-Review \& Editing, JF, SS, DT, LL

Funding: This research received no external funding.

Acknowledgments: W e would like to thank the staff of Camp A bilities for their help with this research.

Conflicts of Interest: Lauren Lieberman is the Director of Camp A bilities.

\section{References}

Ammah, J.O., \& Hodge, S.R. (2005). Secondary physical education teachers' beliefs and practices in teaching students with severe disabilities: A descriptive analysis. The High School Journal, 89(2), 4054. Retrieved from: www.jstor.org/stable/40364238

Bandura, A . (1997). Self-efficacy: The exercise of control. N ew York: Freeman.

Baloun, L., Kudláček, M., Sklenaříková, J., Ješina, O., \& Migdauová, A. (2016). Czech self-efficacy scale for physical education majors towards children with disabilities. Acta Gymnica, 46(1), 44-54. https://doi.org/10.5507/ag.2016.002

Block, M . E., H utzler, Y. S., Barak, S., \& Klavina, A . (2013). Creation and validation of the self-efficacy instrument for physical education teacher education majors toward inclusion. A dapted Physical Activity Quarterly, 30(2), 184-205. https://doi.org/10.1353/hsj.2005.0019

Block, M .E., \& Obrusnikova, I. (2007). Inclusion in physical education: A review of the literature from 1995-2005. Adapted Physical Activity Quarterly, 24(2), 103-124. https://doi.org/10.1123/apaq.24.2.103

Block, M .E., \& Rizzo, T.L. (1995). Attitudes and attributes of physical educators associated with teaching individuals with severe and profound disabilities. Journal of the A ssociation for Persons with Severe Handicaps, 20(1), 80-87. https://doi.org/10.1177/154079699502000108

Block, M ., Taliaferro, A ., H arris, N ., \& Krause, J. (2010). U sing self-efficacy theory to facilitate inclusion in general physical education. Journal of Physical Education, Recreation and Dance, 81(3), 43-46. https://doi.org/10.1080/07303084.2010.10598448

Camerini, A. (2011, September). Full inclusion in Italy: A radical reform. Paper presented at the Conference on Inclusive Education for Children with Disabilities. M oscow. Retrieved from: http://www.unicef.orglceecis/1.Camerini.ppt 
Casebolt, K .M ., \&. H odge, S.R (2010). High school physical education teachers' beliefs about teaching students with mild to severe disabilities. The Physical Educator, 67(3), 140-156.

Clift, R.T ., \& Brady, P. (2005). Research on methods courses and field experiences. In M. Cochran-Smith $\&$ K.M. Zeichner (Eds.), Studying teacher education: The report of the AERA Panel on Research and Teacher Education (pp. 309-424). M ahwah: Lawrence Erlbaum Publishers.

Cohen, J. (1992). A power primer. Psychological Bulletin, 112(1), 155-159.

Conroy, P. (2012). Supporting students with visual impairments in physical education. Insight: Research and Practice in Visual Impairment and Blindness, 5(1), 3-10.

Doulkeridou, A., Evaggelinou, C., Mouratidou, K., Koidou, E., Panagiotou, A., \& Kudláček, M . (2011). A ttitudes of Greek physical education teachers towards inclusion of students with disabilities in physical education classes. International Journal of Special Education, 26(1), 1-11. Retrieved from: https://files.eric.ed.gov/fulltext/E) 921174.pdf

Gao, W., \& Mager, G. (2011). Enhancing preservice teachers' sense of efficacy and attitudes toward school diversity through preparation: A case of one U.S. inclusive teacher education program. International Journal of Special Education, 26(2), 92-107.

Goodwin, D. L., Lieberman, L. J., Johnston, K., \& Leo, J. (2011). Connecting through summer camp: Youth with visual impairments find a sense of community. Adapted Physical Activity Quarterly, 28(1), 40-55. https://doi.org/10.1123/apaq.28.1.40

Goodwin, D. L., \& Staples, K. (2005). The meaning of summer camp experiences to youths with disabilities. A dapted Physical Activity Quarterly, 22(2), 160-178.

https://doi.org/10.1123/apaq.22.2.160

H aegele, J.A., \& Zhu, X. (2017). Experiences of individuals with visual impairments in integrated physical education: A retrospective study. Research Quarterly for Exercise and Sport, 88(4), 425-435. https://doi.org/10.1080/02701367.2017.1346781

H aegele, J.A., Lieberman, L.J., Lepore, M . \& Lepore-Stevens, M . (2014). A service delivery model for physical activity: Camp Abilities, Journal of Visual Impairment and Blindness, 108(6), 473-483. https://doi.org/10.1177/0145482X1410800604

$\mathrm{H}$ ardin, B. (2005). Physical education teachers' reflections on preparation for inclusion. The Physical Educator, 62(1), 44-56.

Kaptein, M. C., Nass, C., \& M arkopoulos, P. (2010). Powerful and consistent analysis of Likert-type rating scales. In Proceedings of the SI GCHI Conference on H uman Factors in Computing Systems (pp. 2391-2394). https://doi.org/10.1145/1753326.1753686

Kodish, S., Kulinna, P. H., M artin, J., Pangrazi, R., \& Darst, P. (2006). D eterminants of physical activity in an inclusive setting. Adapted Physical Activity Q uarterly, 23(4), 390-409.

https://doi.org/10.1123/apaq.23.4.390

Konza, D. (2008). Inclusion of students with disabilities in new times: responding to the challenge. In P. Kell, W. Vialle, D. Konza, \& G. Vogl (Eds). Learning and the learner: exploring learning for new times. U niversity of W ollongong. W ollongong, Australia.

Kozub, F.M ., \& Lienert, C. (2003). A ttitudes toward teaching children with disabilities: Review of literature and research paradigm. Adapted Physical Activity Quarterly, 20(4), 323-346. https://doi.org/10.1123/apaq.20.4.323

Kress, J., \& Lavay, B. (2006). Traveling on the O utBA C-Challenging children with disabilities on a low ropes course. Palaestra, 22(2), 20-26.

Kudláček, M., Baloun, L., \& Ješina, O. (2018). The development and validation of revised inclusive physical education self-efficacy questionnaire for Czech physical education majors. International Journal of Inclusive Education. 24(1), 77-88. https://doi.org/10.1080/13603116.2018.1451562

Kwon, E. H. (2018). Status of introductory APE course and infusion in PETE program. Palaestra, 32(1), 32-39. 
Lancaster, J., \& Bain, A. (2010). The design of pre-service inclusive education courses and their effects on self-efficacy: A comparative study. A sia-Pacific Journal of Teacher Education, 38(2), 117-128. https://doi.org/10.1080/13598661003678950

Lepore, M., Gayle, G. W ., \& Stevens, S. (1998). Adapted aquatics programming: A professional guide. Champaign, IL: Human Kinetics.

Lieberman, L.J., H ouston-W ilson, C., \& Kozub, F.M . (2002) Perceived barriers to including students with visual impairments in general physical education. Adapted Physical Activity Quarterly, 19(3), 364377. https://doi.org/10.1123/apaq.19.3.364.

Lieberman, L. J., Lepore, M ., \& H aegele, J. A . (2014). Camp abilities: a sports camp for children with visual impairments. Palaestra, 28(4), 37.

Lieberman, L.J., \& M cH ugh, B.E. (2001). Health related fitness of children with visual impairments and blindness. Journal of Visual I mpairment \& Blindness, 95(5), 272-286. https://doi.org/10.1177/0145482X0109500503

Lieberman, L.J., Stuart, M., H and, K., \& Robinson, B. (2006). An investigation of the motivational effects of talking pedometers among children with visual impairments and deaf-blindness. Journal of $V$ isual Impairment \& Blindness, 100(12), 726-736. https://doi.org/10.1177/0145482X0610001204

Lienert, C., Sherrill, C., \& Myers, B. (2001). Physical educators' concerns about integrating children with disabilities: A cross-cultural comparison. A dapted Physical Activity Quarterly, 18(1), 1-17. https://doi.org/10.1123/apaq.18.1.1

Lirgg, C.D., Gorman, D.R., M errie, M .D., \& Shewmake, C. (2017). Exploring challenges in teaching physical education to students with disabilities. Palaestra, 31(2), 13-18.

M artin, J. J., \& Kulinna, P. H. (2004). Self-efficacy theory and the theory of planned behavior: Teaching physically active physical education classes. Research Quarterly for Exercise and Sport, 75(3), 288297. https://doi.org/10.1080/02701367.2004.10609161

Martin, J. J., \& Kulinna, P. H. (2005). A social cognitive perspective of physical activity related behavior in physical education. Journal of Teaching in Physical Education, 24(3), 265-281.

\section{https://doi.org/10.1123/jtpe.24.3.265}

M artin, J. J., M cCaughtry, N ., H odges-Kulinna, P., \& Cothran, D. (2008). The influences of professional development on teachers' self-efficacy toward educational change. Physical Education and Sport Pedagogy, 13(2), 171-190. https://doi.org/10.1080/17408980701345683

M artin, J. J., M cCaughtry, N ., Kulinna, P., Cothran, D., \& Faust, R. (2008). The effectiveness of mentoring-based professional development on physical education teachers' pedometer and computer efficacy and anxiety. Journal of Teaching in Physical Education, 27(1), 68-82. https://doi.org/10.1123/jtpe.27.1.68

M inistry of Education and Human Resources. (2007). Special education annual report to congress. Seoul, Korea: M inistry of Education and Human Resources.

M orley, D., Bailey, R., Tan, J., \& Cooke, B. (2005). Inclusive physical education teachers' views of including pupils with special educational needs and/or disabilities in physical education. European Physical Education Review, 11(1), 84-107. https://doi.org/10.1177/1356336X05049826

Norman, G. (2010). Likert scales, levels of measurement and the "laws" of statistics. Advances in Health Sciences Education, 15(5), 625-632. https://doi.org/10.1007/s10459-010-9222-y

Pendergast, D., Garvis, S., \& Keogh, J. (2011). Pre-service student-teacher self-efficacy beliefs: A $n$ insight into the making of teachers. Australian Journal of Teacher Education, 36(12), 46-57. https://doi.org/10.14221/ajte.2011v36n12.6

Perkins, K., Columna, L., Lieberman, L.J ., \& Bailey, J. (2013). Parental perceptions toward physical activity for their children with visual impairments and blindness. Journal of Visual I mpairments and Blindness, 107(2), 131-142. https://doi.org/10.1177/0145482X1310700206 
Piletic, C. K., \& Davis, R. (2010). A profile of the introduction to adapted physical education course within undergraduate physical education teacher education programs. International Council for Health, Physical Education, Recreation, Sport and Dance Journal of Research, 5(2), 26-32. Retrieved from: https://files.eric.ed.gov/fulltext/EJ913329.pdf

Reina, R., Hemmelmayr, I., \& Sierra-M arroquín, B. (2016). Self-efficacy of physical education teachers toward inclusion of students with disabilities and regarding their previous training and experiences. Psychology, Society, \& Education, 8(2) 93-103. Retrieved from: http://ojs.ual.es/ojs/index.php/psye/article/view/455/434

Rust, R., \& Sinelnikov, O . (2010). Practicum in a self-contained environment: Pre-service teacher perceptions of teaching students with disabilities. Physical Educator, 67(1), 33.

Rybová, L., \& Kudlacek, M . (2013). The state of inclusion of students with physical disabilities in general physical education in Prague and Central Bohemian Region. European Journal of Adapted Physical Activity, 6(1), 57-61. https://doi.org/10.5507/euj.2013.005

Schunk, D. H. (2012). Social cognitive theory. In K. R. Harris, S. Graham, \& T. U rdan (Eds.), APA educational psychology handbook, Vol. 1: Theories, constructs, and critical issues (pp. 101-123). Washington, DC: A merican Psychological Association.

Schunk, D. H. , \& Pajares, F. (2009). Self-efficacy theory. In K. R. W entzel \& A. Wigfield (Eds.), Handbook of motivation at school (pp. 35-53). New York, NY: Routledge.

Selickaite, D., Hutzler, Y., Pukenas, K., Block, M.E., \& Rèklaitienè, D. (2019). The analysis of the structure, validity, and reliability of an inclusive physical education self-efficacy instrument for Lithuanian physical education teachers. SAGE Open. https://doi.org/10.1177/2158244019852473

Shapiro, D ., M offett, A ., Lieberman, L.J ., \& Dummer, G. (2005). Perceived competence of children with visual impairments. Journal of Visual Impairment and Blindness, 99(1), 15-25. https://doi.org/10.1177/0145482X0509900103

Taliaferro, A.R., H ammond, L., \& W yant, K. (2015). Preservice physical educators' self-efficacy beliefs toward inclusion: The impact of coursework and practicum. A dapted Physical Activity Quarterly, 32(1), 49-67. https://doi.org/10.1123/apaq.2013-0112

Tindall, D., Culhane, M ., \& Foley, J.T. (2016). Pre-service teachers' self-efficacy towards children with disabilities: An I rish perspective. European J ournal of Adapted Physical Activity Quarterly, 9(1), 27 39. https://doi.org/10.5507/euj.2016.003

Tindall, D., Foley, J.T., \& Lieberman, L. (2016). Incorporating sport education roles for children with visual impairments and blindness as part of a sport camp experience. Palaestra, 30(3), 31-36.

Tschannen-M oran, M ., \& H oy, A. W . (2001). Teacher efficacy: Capturing an elusive construct. Teaching and Teacher Education, 17(7), 783-805. https://doi.org/10.1016/S0742-051X(01)00036-1

United Nations General Assembly Resolution 61/146, Rights of the child, A/RES/61/146 (2006), Retrieved from:

https://www.un.org/en/development/desa/population/migration/generalassembly/docs/globalcomp act/A_RES 61_146.pdf

U.S. Department of Education. (2008). To assure the free appropriate public education of all children with disabilities: Twenty-eighth annual report to Congress on the implementation of the Individuals with Disabilities Education Act. W ashington, DC. Retrieved from: https://www2.ed.gov/about/reports/annual/osep/2006/parts-b-c/28th-vol-1.pdf

(c) 2020 by the authors. Submitted for possible open access publication under the terms and conditions of the Creative Commons Attribution (CC BY) license (http://creativecommons.org/licenses/by/4.0/). 